\title{
Decreased carbon limitation of litter respiration in a mortality-affected piñon-juniper woodland
}

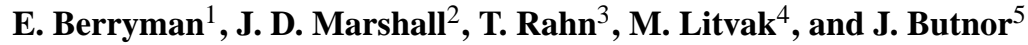 \\ ${ }^{1}$ Department of Forest and Rangeland Stewardship, Colorado State University, 1472 Campus Delivery, Fort Collins, CO, USA \\ ${ }^{2}$ Department of Forest, Rangeland, and Fire Sciences, University of Idaho, CNR 203, Moscow, ID, USA \\ ${ }^{3}$ Earth and Environmental Sciences Division, Los Alamos National Laboratory, Los Alamos, NM, USA \\ ${ }^{4}$ Department of Biology, Castetter Hall Room 133, University of New Mexico, Albuquerque, NM, USA \\ ${ }^{5}$ USDA Forest Service, 81 Carrigan Drive, Aiken Center, Room 210, University of Vermont, Burlington, VT, USA
}

Correspondence to: E. Berryman (erin.berryman@colostate.edu)

Received: 12 September 2012 - Published in Biogeosciences Discuss.: 18 October 2012

Revised: 31 January 2013 - Accepted: 5 February 2013 - Published: 11 March 2013

\begin{abstract}
Microbial respiration depends on microclimatic variables and carbon (C) substrate availability, all of which are altered when ecosystems experience major disturbance. Widespread tree mortality, currently affecting piñon-juniper ecosystems in southwestern North America, may affect C substrate availability in several ways, for example, via litterfall pulses and loss of root exudation. To determine piñon mortality effects on $\mathrm{C}$ and water limitation of microbial respiration, we applied field amendments (sucrose and water) to two piñon-juniper sites in central New Mexico, USA: one with a recent $(<1 \mathrm{yr})$, experimentally induced mortality event and a nearby site with live canopy. We monitored the respiration response to water and sucrose applications to the litter surface and to the underlying mineral soil surface, testing the following hypotheses: (1) soil respiration in a piñonjuniper woodland is water- and labile C-limited in both the litter layer and mineral soil; (2) piñon mortality reduces the $\mathrm{C}$ limitation of litter respiration; and (3) piñon mortality enhances the $\mathrm{C}$ limitation of mineral soil respiration. Litter respiration at both sites responded to increased water availability, yet surprisingly, mineral soil respiration was not limited by water. Consistent with hypothesis 2, C limitation of litter respiration was lower at the recent mortality site compared to the intact canopy site. Applications to the mineral soil showed evidence of reduction in $\mathrm{CO}_{2}$ flux on the girdled site and a non-significant increase on the control. We speculate that the reduction may have been driven by water-induced carbonate dissolution, which serves as a sink for $\mathrm{CO}_{2}$ and would reduce the net flux. Widespread piñon mortality may
\end{abstract}

decrease labile $\mathrm{C}$ limitation of litter respiration, at least during the first growing season following mortality.

\section{Introduction}

Arid and semi-arid ecosystem processes are dynamic over time, pulsing in response to rainfall events (Reynolds et al., 2004; Schwinning and Sala, 2004). Rain stimulates net ecosystem carbon dioxide $\left(\mathrm{CO}_{2}\right)$ exchange by affecting leaflevel gas exchange, ecosystem and soil respiration (Sala and Lauenroth, 1982; Potts et al., 2006; Jenerette et al., 2008). The response of soil respiration to small $(<5 \mathrm{~mm})$ rain events is fueled by heterotrophs utilizing soil organic carbon (C), rather than autotrophs, because such events often cannot be accessed by vegetation; thus, small rain events lead to net $\mathrm{C}$ loss from these systems (Huxman et al., 2004; Carbone et al., 2011). Predicting future climate effects on soil $C$ requires a better understanding of controls over, or limitations to, arid and semi-arid respiration.

Fundamentally, heterotrophic $\mathrm{C}$ mineralization is controlled by temperature, moisture, and substrate supply (Witkamp, 1966; Parton et al., 1994; Schimel and Weintraub, 2003). Temperature plays a minor role in very dry conditions and, therefore, is more important when moisture is not restrictive (Conant et al., 2004; Curiel Yuste et al., 2007; Carbone et al., 2011). Increases in soil moisture enhance substrate availability for microorganisms, which typically increases respiration rates and enhances temperature 
sensitivity of respiration (Davidson and Janssens, 2006; Borken and Matzner, 2009). However, high moisture levels may suppress respiration if soil pores fill and gas diffusion is restricted (Greenwood, 1961). Quality of substrate is important; labile $\mathrm{C}$ compounds, such as sugars, yield higher respiration rates than lower quality substrate, such as recalcitrant soil organic matter (Bosatta and Ågren, 1999). Thus, greatest respiration rates might occur under high temperatures, moderate to high moisture levels and high labile $\mathrm{C}$ supply. However, limitation to respiration has yet to be quantified for all these factors simultaneously in a semi-arid system.

Because of their high frequency, small rain pulses stimulate a significant portion of the total annual respiration in dryland systems (Huxman et al., 2004). The heterotrophic response to a rain pulse in dry systems consists of a large initial response that declines over time (Birch, 1958) and is referred to as a Birch effect. The decline of respiration following a post-rainfall pulse is often attributed to water limitation coincident with rapid surface drying (Cable and Huxman, 2004; Huxman et al., 2004). However, what appears to be a drying effect could instead result from rapid consumption and depletion of labile substrate. Previous research in a semi-arid shrubland soil suggests that labile $\mathrm{C}$ depletion occurs within two to three days of wetting (Saetre and Stark, 2005). This theory of labile substrate depletion could explain the finding that Sonoran Desert soil respiration demonstrated a threshold response to artificial rain event size (Sponseller, 2007). Thus, the size of the Birch effect may be more site-specific and could depend on limitation by labile $\mathrm{C}$ availability in addition to water limitation.

The widespread piñon mortality that has occurred in the US southwest (Breshears et al., 2005) has likely altered key factors that regulate the Birch effect. Increases in soil temperature and drying of the litter surface may result from increased solar radiation penetration following canopy loss. Counteracting these effects, the loss of transpiring roots may increase water stored in soil. The fall of dead piñon needles would increase $\mathrm{C}$ supply in the litter; $\mathrm{C}$ supply to the rhizosphere would decline with the loss of live, exuding roots. The net effect of these changes on the Birch effect is difficult to predict without understanding limiting factors to respiration rates in semi-arid systems. We used field manipulations to assess water and labile $\mathrm{C}$ limitation of respiration in a piñon-girdling experiment in central New Mexico. To establish the repeatability of our approach, we first conducted two experiments in an intact piñon-juniper woodland. We then conducted a third set of experiments that compared the intact site to a site that experienced a mass piñon mortality event. Our main hypotheses were the following:

1. soil respiration in a piñon-juniper woodland is waterand labile C-limited in both the litter layer and mineral soil;

2. piñon mortality reduces the $\mathrm{C}$ limitation of litter respiration; and
3. piñon mortality enhances the $\mathrm{C}$ limitation of mineral soil respiration.

\section{Materials and methods}

\subsection{Site description}

Our study site was located in a piñon-juniper woodland in central New Mexico, USA, on an extended mesa at an elevation of $2100 \mathrm{~m}$ a.s.l. (Chupadera Mesa, $34.3585^{\circ} \mathrm{N}$, $-106.266^{\circ} \mathrm{W}$ ). The climate is characterized by mild winters and hot, dry summers with sporadic heavy rains during the monsoon season, typically July through September. The woodland was comprised of two tree species, Pinus edulis and Juniperus monosperma, with a sparse understory of $\mathrm{C}_{3}$ (Oryzopsis hymenoides) and $\mathrm{C}_{4}$ grasses (Bouteloua gracilis (H.B.K.) Lag.). The soil is a lithic mollic Calciorthid (piñon channery loam, Soil Survey Staff, NRCS); soil pH ranged from 7.3 to 7.7 (D. Warnock, personal communication). Both sites were flat ( $\sim 0 \%$ slope) and experienced similar weather conditions throughout the experiment. One site remained unaltered (reference), and the other site (girdled) experienced a girdling treatment to induce piñon mortality. The leaf area index from piñon was about $0.65 \mathrm{~m}^{2} \mathrm{~m}^{-2}$ at the reference site and $0.55 \mathrm{~m}^{2} \mathrm{~m}^{-2}$ at the girdled site prior to girdling. In September 2009 during a four-day period at the girdled site, all piñon trees above $7 \mathrm{~cm}$ diameter at breast height (dbh) within a 4-ha area were girdled using chainsaws, and the cuts were sprayed with herbicide (glyphosate) to ensure mortality. Mortality of treated trees was confirmed in spring 2010. Based on allometric relationships, litterfall from girdled trees was equivalent to $0.22 \mathrm{~kg} \mathrm{C} \mathrm{m}^{-2}$. Replication of the girdling treatment was sacrificed so that a spatial scale large enough for the goals of the broader study could be achieved. Thus, site differences are specific to the girdling treatment applied and should not be extrapolated to generalize mortality effects in piñon-juniper ecosystems. To establish repeatability of our methods, we conducted two experiments in the reference site starting 7 July ("experiment 1") and $10 \mathrm{Au}$ gust ("experiment 2") 2010. We conducted a comparison of the girdled and reference site limitations in a simultaneous dual-site experiment beginning 16 August 2010 ("girdledreference comparison experiment").

\subsection{Soil and litter properties}

To compare soil $\mathrm{C}: \mathrm{N}$ between the girdled and reference site, on 16 August 2010, soil and surface litter samples were collected from each site for analysis of organic $\mathrm{C}$, inorganic $\mathrm{C}$ and nitrogen $(\mathrm{N})$ content. Mineral soil cores $(0-10 \mathrm{~cm})$ and overlying litter were collected from five replicate locations underneath piñon canopies, sieved to remove coarse roots and rocks $(2 \mathrm{~mm})$ and dried at $60^{\circ} \mathrm{C}$. Samples were homogenized in a ball mill before being analyzed for total $\mathrm{C}$ and $\mathrm{N}$ content on an elemental analyzer (TruSpec, LECO Corp., 
St. Joseph, MO). Total $\mathrm{C}$ was adjusted to organic $\mathrm{C}$ by subtracting inorganic $\mathrm{C}$ content (as $\mathrm{CaCO}_{3}$ ), which was determined on subsamples by treating them with $6 \mathrm{~N} \mathrm{HCl}$ in closed vials and monitoring the pressure of the headspace gas resulting from $\mathrm{CO}_{2}$ generation (Sherrod et al., 2002).

Soil and litter layer moisture was monitored at areas analogous to, but not the same as, those captured by soil chambers at each site. Gravimetric moisture was determined by mass loss after oven drying $\left(60^{\circ} \mathrm{C}\right)$ for litter samples collected from both sites on 16 and 25 August 2010, representing the start and end dates of the girdled-reference comparison experiment. Volumetric soil moisture content was monitored throughout the experimental period using CS616 sensors (Campbell Scientific, Logan, UT) placed at three depths $(5 \mathrm{~cm}, 10 \mathrm{~cm}$, and $30 \mathrm{~cm}$ below the mineral soil surface) underneath three different piñon canopies at each site.

\subsection{Experimental treatments}

We assessed water and labile $\mathrm{C}$ limitation of respiration at both sites by monitoring the response of respiration to water and sucrose solutions. Fifteen individual experimental areas (each $491 \mathrm{~cm}^{2}$ ) were selected for proximity to piñon trees $(30 \mathrm{~cm}$ from the stem) and presence of a piñon needle litter layer. Over 12 of the experimental areas, we applied treatment solutions evenly using a syringe and needle; three areas were retained as untreated controls ("untreated"). Treatments were applied to either the top of the surface litter or to the top of the mineral soil underneath the litter. Immediately after solution applications to the mineral soil, the litter layer was replaced. Four treatments were applied. Three areas received a pure distilled water application of $1222 \mathrm{~mL} \mathrm{~m}^{-2}(1.2 \mathrm{~mm})$ to the litter surface ("litter water" treatment). Three areas received the same amount of distilled water to the mineral soil surface ("soil water" treatment), taking care to minimize disturbance to the litter when removing it or replacing it after treatment. Three areas received $1222 \mathrm{~mL} \mathrm{~m}^{-2}$ of a sucrosedistilled water solution $\left(0.463 \mathrm{~mol}\right.$ sucrose $\mathrm{L}^{-1}$, commercial grade) applied to the litter surface ("litter sucrose" treatment), and three areas received $1222 \mathrm{~mL} \mathrm{~m}^{-2}$ of the sucrose solution to the mineral soil surface in the same fashion as the pure distilled water treatment ("soil sucrose" treatment). Sucrose applications were equivalent to $6.8 \mathrm{~mol} \mathrm{C} \mathrm{m}^{-2}$. At a "typical" microbial respiration rate of $2 \mu \mathrm{mol} \mathrm{C} \mathrm{m}{ }^{-2} \mathrm{~s}^{-1}$, this would have represented nearly 40 days' worth of substrate. For each repeat experiment, different areas were selected so that no area received multiple treatments through time.

\subsection{Respiration response}

We monitored the response of respiration for five days following treatment application. Immediately after application, each treated area was covered with a PVC chamber connected to an Automated Carbon Efflux System (ACES) (Butnor et al., 2003). The respiration system sequentially mea- sured $\mathrm{CO}_{2}$ concentration and flow rates to and from a series of 16 chambers each covering a surface area of $491 \mathrm{~cm}^{2}$ (including one null chamber) and calculated respiration rates using an open-system approach. Chambers were covered in reflective insulation (Reflectix, Inc., Markleville, IN) to prevent heating. The system switched chambers once every $10 \mathrm{~min}$, completing one cycle every $160 \mathrm{~min}$. When chambers were not being sampled, ambient air was circulated through the chambers at a rate of $1.5 \mathrm{~L} \mathrm{~min}^{-1}$ to minimize buildup of chamber $\left[\mathrm{CO}_{2}\right]$ and prevent disruption of the ambient soilair $\left[\mathrm{CO}_{2}\right]$ gradient.

Thermocouples (Omega Engineering, Omaha, NE) in each chamber measured soil temperature at $5 \mathrm{~cm}$ and chamber air temperature at $5 \mathrm{~cm}$ above the surface. The treatments were timed to occur $20 \mathrm{~min}$ before each chamber was sampled for the first time. Similarly, "untreated" chambers were inserted over an untreated area $20 \mathrm{~min}$ prior to the first chamber measurement.

\subsection{Labile $\mathbf{C}$ and water limitation calculations}

We defined "limitation" as a response in respiration to the addition of either water or sucrose relative to respiration in a control (Ekblad and Nordgren, 2002; Schaeffer et al., 2003). To quantitatively assess limitations, we calculated the percent increase in respiration in response to the treatments relative to its respective control, as outlined by Kim et al. (2012). We determined water limitation by comparing the respiration response from the water treatments to the untreated respiration. We determined labile $\mathrm{C}$ limitation by comparing the respiration response from the sucrose treatments to the response from the water treatments, because the same amount of water was added in both treatments and we were interested in the elevation of respiration due to the presence of sucrose above that of wetting. Limitations were calculated for labile $\mathrm{C}$ and water in both the litter and mineral soil as follows:

Limitation $=\frac{100\left(R_{\text {Treated }}-R_{\text {Control }}\right)}{R_{\text {Control }}}$,

where $R_{\text {Treated }}$ is the mean instantaneous respiration rate from the treated areas and $R_{\text {Control }}$ is the mean instantaneous respiration rate from the treatment's respective control. For water limitation, the control is the untreated respiration rate; for labile $\mathrm{C}$ limitation, the control is the water-treated respiration rate. We calculated limitations using both instantaneous flux rates and cumulative $C$ respired since treatment application. First, we used the instantaneous flux rates from the reference site only to obtain a time series of respiration responses for the duration of the 7 July and 10 August experiments using synchronous respiration rates among treatments. Then, from these time series we selected three different time periods following treatment application from which to calculate cumulative respiration responses. These cumulative responses were used to compare limitations between the girdled site and the reference site. We determined appropriate 
time windows by considering the amount of time for respiration to peak following treatment application and begin to flatten out. Cumulative limitations were calculated for each chamber from cumulative sums of respiration rates using linear interpolation between measurement time points. The limitation was calculated according to Eq. (1) but using the individual chamber cumulative respiration for $R_{\text {Treated }}$ and the mean cumulative respiration rate from the treatment's respective control for $R_{\text {Control }}$.

\subsection{Statistical analyses}

We investigated differences among treatment effects using non-linear mixed-effects modeling. Initial assessment revealed that respiration decayed over time following treatment and also fluctuated consistently with diel variation in soil and air temperature. Thus, we fit our data to an exponential decay model (Eq. 2) that also included a temperature sensitivity parameter. Because respiration often increases exponentially with temperature (Lloyd and Taylor, 1994), we first included an exponential temperature function along with the decay function:

$R=R_{\max } \exp (-k t)+\exp \left(\gamma T_{\text {soil }}\right)+\beta$,

where $R$ is the respiration rate for each treatment and time

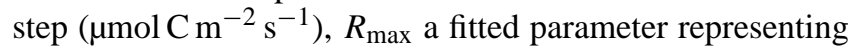
the maximum respiration response to the treatment, $k$ a fitted parameter representing the decay of respiration over time, $t$ time following treatment application (days), $\gamma$ a fitted parameter representing temperature sensitivity, $T_{\text {soil }}$ soil temperature at $5 \mathrm{~cm}$ (mineral soil and untreated) or chamber air temperature (litter), and $\beta$ an intercept, which was allowed to vary randomly for each chamber. If model parameterization failed due to lack of convergence, we re-fit the data using a linear temperature function as shown in Eq. (3).

$R=R_{\max } \exp (-k t)+\gamma T_{\text {soil }}+\beta$

We used PROC NLMIXED in SAS ${ }^{\circledR}$ to fit the fixed and random parameters for each treatment, analyzing data from each experiment date separately. Significant treatment effects were determined by fitting parameters defined as differences among treatments and testing their equivalence to zero. Water-treated respiration parameters were compared to the untreated respiration parameters. To detect if sucrose had an effect beyond that of water, parameters from the sucrose treatment were compared to the water treatment.

To determine if limitations differed between the reference site and the girdled site, we used a t-test to compare the cumulative treatment responses from the reference site to the Girdle site ( $n=3$ for each treatment class and site). We assessed cumulative responses to treatments from three different time periods: during the first three measurements following treatment applications $(8 \mathrm{~h})$, during the first $36 \mathrm{~h}$, and during the entire experiment $(115 \mathrm{~h})$. We determined dif- ferences in $\mathrm{C}: \mathrm{N}$, percent $\mathrm{N}$, and cumulative treatment responses between sites for each location (litter or mineral soil) and each limiting factor ( $\mathrm{C}$ or water) using a t-test if normality and homoscedasticity assumptions were met; otherwise, the Mann-Whitney rank sum test was used. t-tests were conducted using R (R Development Core Team 2011); repeated-measures ANOVAs, multiple comparisons and nonlinear modeling were conducted using SAS ${ }^{\circledR}$ after confirming that data met assumptions of these tests. Unless otherwise indicated, $\alpha=0.05$.

\section{Results}

Consistent with our hypotheses, respiration responded to both water and sucrose additions and results were similar for the repeated experiments conducted at the reference site (Fig. 1). Solution applications to the litter surface yielded stronger immediate respiration responses than solution applications to the mineral soil (Table $1 R_{\max }$; Fig. $1 \mathrm{~b}$ and e vs. $\mathrm{c}$ and $\mathrm{f}$ ).

Nonlinear model parameters revealed treatment effects on the Birch effect and temperature sensitivity of respiration. Respiration rates were affected by temperature as indicated by the significant linear temperature coefficients $(\gamma$; Table 1); non-linear temperature parameters resulted in nonconvergence of the models. Some sucrose and water treatments increased temperature sensitivity (bold $\gamma$ values in Table 1). Comparing the respiration decay constants $(k)$ among the treatments revealed two key findings. First, the reduced $k$ in the sucrose applications compared to the water applications helped sustain a detectable sucrose effect over that of water (Fig. 1b, c, e, and f). Thus, labile $\mathrm{C}$ limitation peaked later than water limitation (Figs. 2 and 3). Second, the low $k$ following treatments to the mineral soil indicated that the sucrose effect was longer-lasting compared to the litter treatment response (Fig. 3b).

Temperature and moisture differed between the site with girdled piñons (girdled site) and the undisturbed reference site. Chamber temperatures were $1.6^{\circ} \mathrm{C}$ warmer at the girdled site than the reference site in the soil $(5 \mathrm{~cm} ; P<0.0001)$ and $2.7^{\circ} \mathrm{C}$ warmer in the chamber air $(P<0.0001$; Fig. 4$)$. Litter moisture was greater at the reference site than at the girdled site on the day the treatments were applied (Table 2; $P=0.006)$. After the experiment ended, there was no difference in litter moisture between the two sites $(P=0.25)$. Soil moisture sensors showed declining water content over the course of the experiment; soil water content was similar between the two sites at $10 \mathrm{~cm}$ and $30 \mathrm{~cm}$ depth, but soil at $5 \mathrm{~cm}$ was drier at the reference site, indicating increased soil water storage at the girdled site ( $n=3$ per depth, Fig. 5). Neither $\mathrm{C}: \mathrm{N}$ nor percent $\mathrm{N}$ varied among the two sites in surface soil $(P=0.62$ and $P=0.59)$ and litter $(P=0.70$ and $P=0.18$ ) collected 16 August 2010 (Table 2). 
Table 1. Results of non-linear mixed effects modeling of the temporal respiration response to treatments using the following model: $R=$ $R_{\max } \exp (-k t)+\gamma T_{\text {soil }}+\beta$, where $R_{\max }$ indicates the initial respiration rate following solution applications, $k$ indicates the decay of respiration over time, and $\gamma$ is the temperature sensitivity of respiration. Bold values indicate parameters that were significantly different from the untreated (for water treatments) or water-treated (for sucrose treatments) parameters $(\alpha=0.05)$. $P$ values for significance of parameters: ${ }^{*} \leq 0.05 ;^{* *} \leq 0.01 ;^{* *} \leq 0.001$.

\begin{tabular}{|c|c|c|c|c|c|}
\hline $\begin{array}{l}\text { Experiment } \\
\text { start date }\end{array}$ & Site & Treatment & $R_{\max }$ & $k$ & $\gamma$ \\
\hline \multirow[t]{5}{*}{7 July } & \multirow[t]{5}{*}{ Reference } & untreated & 0.07 & -0.24 & -0.01 \\
\hline & & soil water & $0.98^{*}$ & $2.40^{* *}$ & -0.01 \\
\hline & & soil sucrose & 0.38 & $0.44^{*}$ & $0.06 * *$ \\
\hline & & litter water & $1.45^{* * *}$ & $0.67^{* *}$ & 0.01 \\
\hline & & litter sucrose & $3.57^{* * *}$ & $2.32^{*}$ & -0.01 \\
\hline \multirow[t]{5}{*}{10 August } & & untreated & 0.45 & 0.20 & -0.014 \\
\hline & & soil water & 0.33 & 0.49 & 0.014 \\
\hline & & soil sucrose & 0.24 & -0.047 & 0.022 \\
\hline & & litter water & $2.28^{* * *}$ & $0.85^{*}$ & -0.0036 \\
\hline & & litter sucrose & $6.83^{* * *}$ & 0.79 & $\mathbf{0 . 0 1 8}^{* *}$ \\
\hline \multirow[t]{10}{*}{16 August } & \multirow[t]{5}{*}{ Reference } & untreated & 0.53 & 0.19 & $-0.015^{* *}$ \\
\hline & & soil water & 0.55 & 0.45 & -0.01 \\
\hline & & soil sucrose & $1.65^{*}$ & 0.11 & -0.0045 \\
\hline & & litter water & $\mathbf{2 . 4 3} \mathbf{3}^{* * *}$ & $0.826^{*}$ & 0.012** \\
\hline & & litter sucrose & $\mathbf{6 . 8 6}^{* * *}$ & $0.50^{* *}$ & 0.017 \\
\hline & \multirow[t]{5}{*}{ Girdled } & untreated & 0.23 & 0.33 & 0.0040 \\
\hline & & soil water & 0.54 & 0.57 & -0.0048 \\
\hline & & soil sucrose & 1.10 & 0.15 & -0.0026 \\
\hline & & litter water & $2.71^{* * *}$ & $1.21^{*}$ & $-0.0048^{*}$ \\
\hline & & litter sucrose & $4.17^{* * *}$ & 1.04 & $0.00966^{* *}$ \\
\hline
\end{tabular}

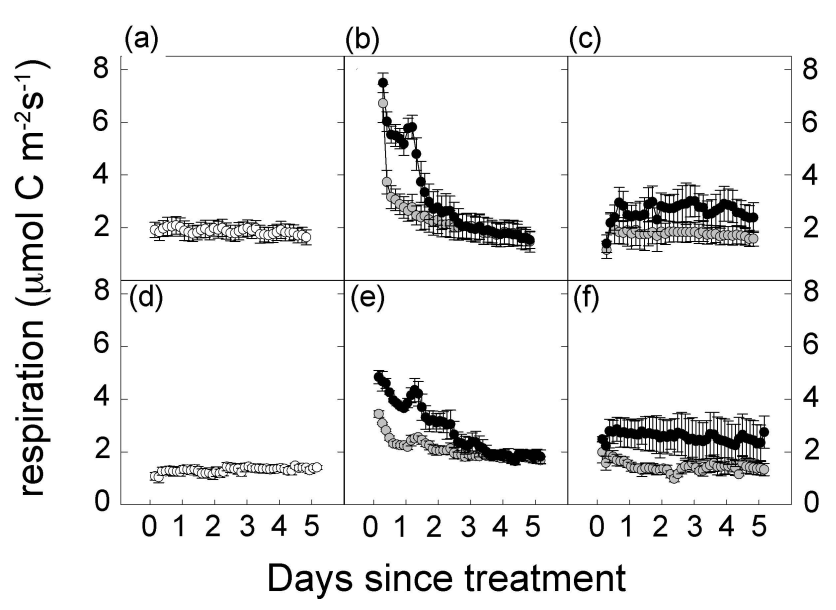

Fig. 1. Reference site experiment 1 (top row) and experiment 2 (bottom row) mean respiration $( \pm 1 \mathrm{SE})$ in $(\mathbf{a}, \mathbf{d})$ control, $(\mathbf{b}, \mathbf{e})$ litter surface, and (c, f) mineral soil applications. Light grey symbols indicate water-only, and black symbols indicate sucrose+water treatments.

Water and sucrose treatments to the litter affected respiration at the girdled site differently than the reference site (Fig. 6). The initial response $\left(R_{\max }\right)$ to sucrose was higher at the reference site than the girdled site, whereas responses

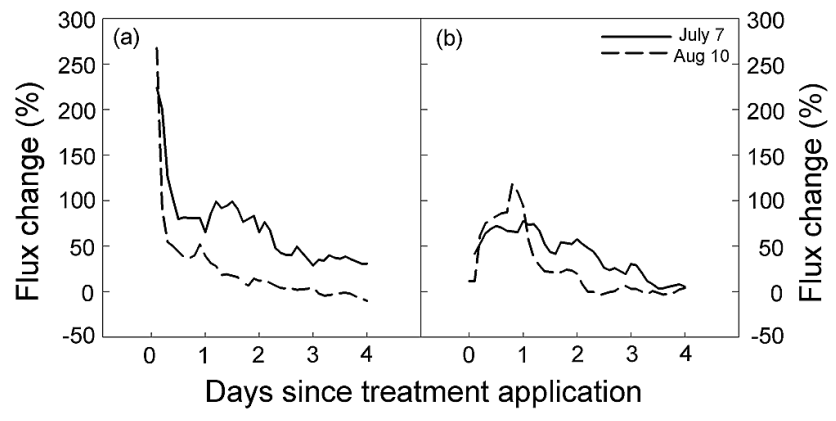

Fig. 2. Limitation of litter respiration to (a) water and (b) sucrose over time for reference site experiments 1 (7 July) and 2 (10 August 2010).

to water applications were more similar (Table 1). Respiration pulses decayed faster at the girdled site compared to the reference site; this was true for both water and sucrose applications to the litter (Table 1).

Cumulative limitations revealed some differences between the reference site and the girdled site (Fig. 7). The difference in the response of respiration to water additions to the litter was largest during the first $8 \mathrm{~h}$, but this was not significant (Fig. 7, top left). Cumulative respiration responses to sucrose 
Table 2. Properties of soil samples collected underneath piñon canopies on 16 August 2010 from the $0 \mathrm{~cm}$ to $10 \mathrm{~cm}$ depth and litter layer samples collected just above the mineral soil surface at the same locations as the soil samples. $\mathrm{BD}=$ bulk density, $\mathrm{IC}=$ inorganic $\mathrm{C}, \mathrm{CCE}=\% \mathrm{CaCO}_{3}$ equivalent, $\mathrm{SWC}=$ soil water content, $\mathrm{LWC}=$ litter water content, $\mathrm{OC}: \mathrm{N}=$ organic $\mathrm{C}$ to total nitrogen ratio. Values in parentheses are the SE of the mean $(n=5)$. Different superscript letters denote values that are significantly different between the two sites $(\alpha=0.05)$. * Bulk density measurements were conducted one year prior to study and represent the average of two samples collected at $5 \mathrm{~cm}$ depth.

\begin{tabular}{lll}
\hline & Reference & Girdled \\
\hline $\mathrm{BD}^{*}\left(\mathrm{~g} \mathrm{~cm}^{-3}\right)$ & 1.44 & 1.02 \\
$\mathrm{IC}(\mathrm{CCE})$ & $0.82(0.31)$ & $0.87(0.54)$ \\
$\mathrm{SWC}\left(\mathrm{g} \mathrm{H}_{2} \mathrm{O} \mathrm{g}^{-1}\right.$ dry) & $0.08(0.02)$ & $0.08(0.03)$ \\
$\mathrm{LWC}\left(\mathrm{g} \mathrm{H}_{2} \mathrm{O} \mathrm{g}^{-1}\right.$ dry) & $0.12^{\mathrm{b}}(0.01)$ & $0.06^{\mathrm{a}}(0.01)$ \\
$\% \mathrm{~N}-$ soil & $0.28(0.06)$ & $0.33(0.05)$ \\
$\% \mathrm{~N}-$ litter layer & $1.23(0.06)$ & $1.01(0.14)$ \\
$\mathrm{OC}: \mathrm{N}-$ soil & $13.2(0.33)$ & $12.9(0.43)$ \\
$\mathrm{OC}: \mathrm{N}-$ litter layer & $33.1(2.2)$ & $34.4(2.5)$ \\
\hline
\end{tabular}

treatments to the litter exhibited the largest between-site differences when calculated over the first $36 \mathrm{~h}$ (7, middle right) compared to during the first $8 \mathrm{~h}$ after treatments and over the entire experiment duration $(115 \mathrm{~h})$. Labile $\mathrm{C}$ limitation of litter respiration was higher at the reference site than at the girdled site both $36 \mathrm{~h}$ and $115 \mathrm{~h}$ following treatment application. Water limitation of respiration in the mineral soil was higher at the reference site than the girdled site; this was because water applications to the mineral soil at the girdled site actually reduced respiration below that of the untreated areas. Limitation of respiration to labile $\mathrm{C}$ in the mineral soil was positive and similar between the two sites due to high variability at the reference site (Fig. 7, far right).

\section{Discussion}

Consistent with previous work, water additions to litter stimulated respiration (Fig. 1; Kelliher et al. 2004; Cisneros Dozal et al. 2007). We expect that similar processes are operating in the litter layer that also produce a Birch effect from soil surfaces, e.g., release of substrate from microbial cells, enhanced access to substrate via water channels, and resulting stimulation of respiration of more recalcitrant C ("priming") (Fierer and Schimel, 2003; Borken and Matzner, 2009; Kim et al., 2012). Thus, both water and substrate limitation are alleviated by wetting events. Our approach of adding the same amount of rainfall both with and without additional sucrose allowed us to detect further limitation of respiration to labile substrate following wetting.

Because less than $10 \%$ of added sucrose was respired above that of the water-only treatment, the decline in respiration from its peak likely resulted from drying. Even

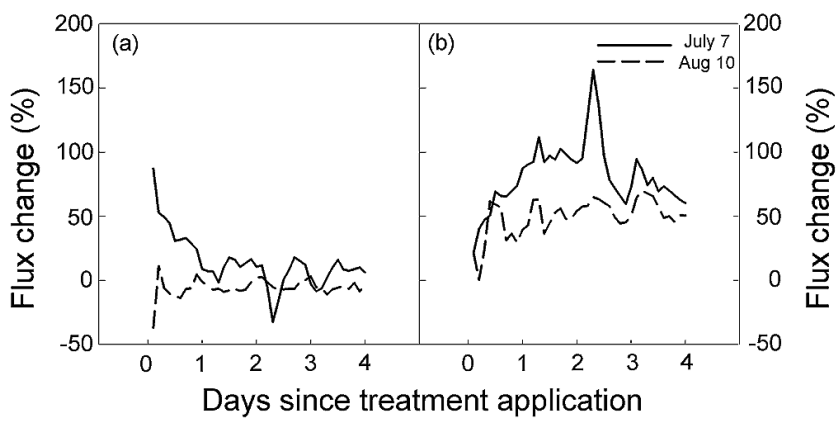

Fig. 3. Limitation of mineral soil respiration to (a) water and (b) sucrose over time for reference site experiments 1 (7 July) and 2 (10 August 2010).

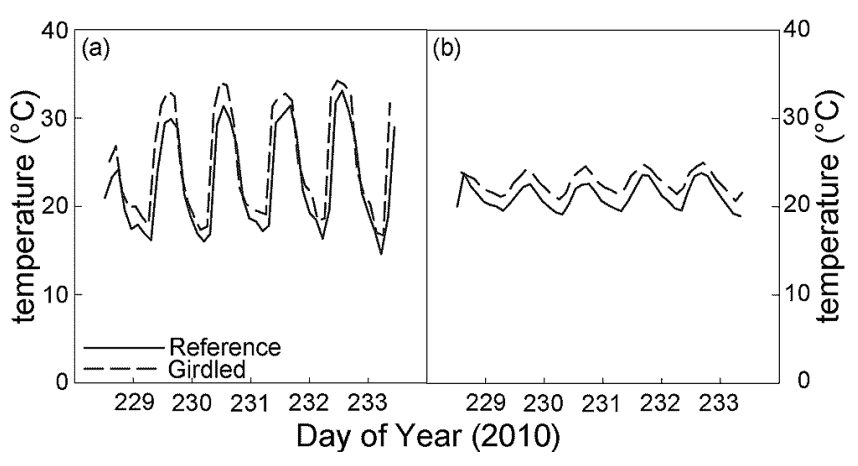

Fig. 4. Temperatures in the soil respiration chambers during the girdled-reference comparison experiment in the (a) air and (b) soil at $5 \mathrm{~cm}$; the reference site is indicated by the solid line and the girdled site by the dotted line.

during the dry-down, respiration from sucrose-treated litter was higher than respiration from water-treated litter (Fig. 2), suggesting that respiration from the water-treated areas was lower than its potential given the availability of more substrate. Thus, the Birch effect in the litter is limited by labile $\mathrm{C}$ availability after a small wetting event, at least until the litter dries enough to restrict respiration. Labile $\mathrm{C}$ limitation has been directly tested in mesic forests and deserts (Ekblad and Nordgren, 2002; Schaeffer et al., 2003); we provide the first direct test in a semi-arid woodland. Therefore, if labile $\mathrm{C}$ is depleted post-wetting in semi-arid ecosystems (Saetre and Stark, 2005), the size of the Birch effect might depend on the level of substrate availability as well as the rain event size (Sponseller, 2007).

Further, our results suggest that a piñon mortality event reduces limitation of respiration to labile $\mathrm{C}$ in the litter (Fig. 7). Labile $\mathrm{C}$ availability in the litter layer may have increased as a result of the influx of dead needles, reducing the dependence of respiration on labile $\mathrm{C}$ and shifting it to another variable. Enhancement of substrate availability through chemical changes could have occurred via increased photodegradation (Gallo et al., 2009), another possible effect of tree mortality due to opening of the canopy. The loss of canopy could also 


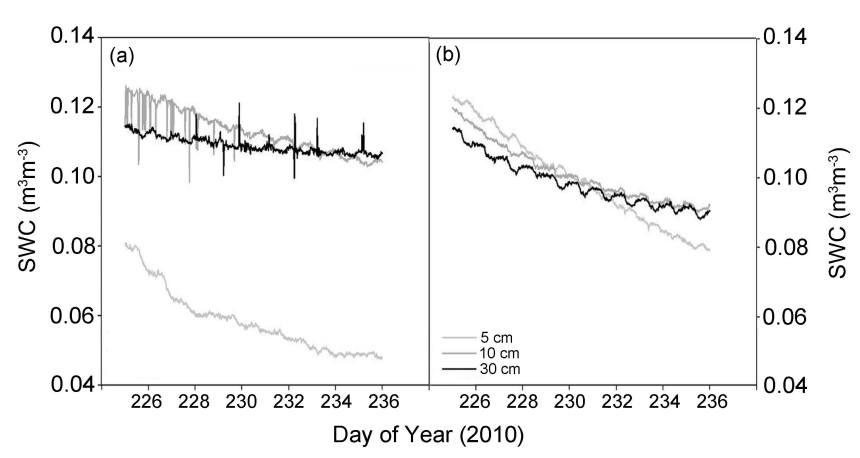

Fig. 5. Soil moisture at the (a) reference and (b) girdled sites $(n=3$ for each depth) during the girdled-reference comparison experiment.

have increased surface drying, shifting the limitation of respiration away from labile $\mathrm{C}$ towards water availability.

Supporting the latter argument, both water and sucrose applications to the litter yielded respiration pulses that declined faster at the girdled site than at the reference site $(k$ in Table 1). More rapid decay of the respiration pulse at the girdled site may have resulted from faster drying of the litter layer. Faster drying may have resulted from a more open canopy at the girdled site and higher solar radiative flux warming the air in contact with the litter layer, thus increasing the litterair vapor pressure gradient and drying the litter faster. Yet, water limitation in the litter was not different between the two sites; in fact, it may have been higher during the first $8 \mathrm{~h}$ at the girdled site (Fig. 7). We propose that increased drying at the girdled site caused a rapid decline in respiration after the wetting pulse, countering the initial higher response and thus yielding no difference in cumulative $\mathrm{C}$ respired over the duration of the experiment compared to the reference site (Fig. 7; Table 1). Our comparison of cumulative respiration responses from three different durations following treatment application accounts for different temporal phases of a respiration pulse following a rain event. The meaningful interpretation of respiration peaks and decay rates in the context of substrate availability and abiotic influences warrants further study.

Nitrogen $(\mathrm{N})$ availability could also have affected our assessment of labile $\mathrm{C}$ limitations. Lower $\mathrm{C}: \mathrm{N}$ of substrate can reduce microbial competition for available $\mathrm{N}$ and can both enhance mineralization of labile $\mathrm{C}$ and reduce priming of recalcitrant C (Ziegler and Billings, 2011; Nottingham et al., 2009). Previous research has found reduced $C: N$ of litter from dead trees (Morehouse et al., 2008; Griffin et al., 2011). Contrary to these findings, litter layer $\mathrm{C}: \mathrm{N}$ was no different between the girdled and reference sites. Opening of the girdled site canopy following needle drop may have increased abiotic gaseous $\mathrm{N}$ loss from the litter surface (McCalley and Sparks, 2009), counteracting a reduction in girdled site litterfall $\mathrm{C}: \mathrm{N}$. We cannot conclude that differences in $\mathrm{N}$ availability explain the differences in labile $\mathrm{C}$ limitation between the two sites; post-mortality $\mathrm{N}$ limitation should be further examined.

Applications of water to the mineral soil surface yielded either no detectable response (reference site) or reduced respiration compared to untreated (girdled site). A C uptake mechanism may have counteracted the boost in respiration expected from the mineral soil after a rain event. We ruled out autotrophic $\mathrm{C}$ uptake, because cyanobacteria-containing soil crusts, while common in the interspaces between trees at both sites, were not detectable underneath the litter layer where our experiments were conducted. A remaining explanation could be abiotic $\mathrm{C}$ uptake due to soil carbonate dissolution and precipitation. Over short time scales, dissolution and precipitation of calcium carbonate depends on the activity of carbonic acid formed when $\mathrm{CO}_{2}$ dissolves in water, as might occur in basic soils with high levels of biological $\mathrm{CO}_{2}$ generation. The overall reactions can be summarized as follows (Plummer and Busenberg, 1982):

$\mathrm{H}_{2} \mathrm{O}_{(\mathrm{aq})}+\mathrm{CO}_{2(\mathrm{~g})}+\mathrm{CaCO}_{3(\mathrm{~s})} \Leftrightarrow 2 \mathrm{HCO}_{3(\mathrm{aq})}^{-}+\mathrm{Ca}^{2+}{ }_{(\mathrm{aq})}$.

According to Eq. (4), carbonate dissolution is a sink for $\mathrm{CO}_{2}$ and precipitation is a source for $\mathrm{CO}_{2}$. Thus, soil respiration may be reduced after water additions if carbonate were dissolved. Upon soil drying, $\mathrm{CaCO}_{3}$ would re-precipitate, increasing soil $\mathrm{CO}_{2}$ evolution. These mechanisms could explain the negative response at the girdled site and the imperceptible response at the reference site to water applications to the mineral soil. In contrast to the water applications, sucrose applications to the mineral soil increased respiration significantly above the water control, suggesting that additional carbon stimulated microbial respiration enough to overcome initial $\mathrm{CO}_{2}$ uptake during carbonate dissolution. Respiration responses to substrate additions in the laboratory have been "corrected" for the influence of calcite processes (Oren and Steinberger, 2008). However, abiotic fluxes of $\mathrm{CO}_{2}$ can be as large as biological fluxes in areas with carbonate bedrock (Serrano-Ortiz et al., 2010); this mechanism should be considered during interpretation of instantaneous respiration rates in arid and semi-arid calcareous soils.

In addition to moisture and labile $\mathrm{C}$, temperature was also important for respiration. The effect of temperature increased for some of the sucrose treatments, suggesting an interaction effect among temperature, moisture and labile $\mathrm{C}$ supply on soil respiration. Our results support the theory that temperature sensitivity is enhanced at high levels of both soil moisture and substrate availability (Davidson and Janssens, 2006). Our findings also suggest that a temperature-moisture interaction effect might be most apparent at high labile $\mathrm{C}$, pointing to a possible mechanism for temperature and moisture interaction effects on soil respiration measured in the field (Suseela et al., 2011). 


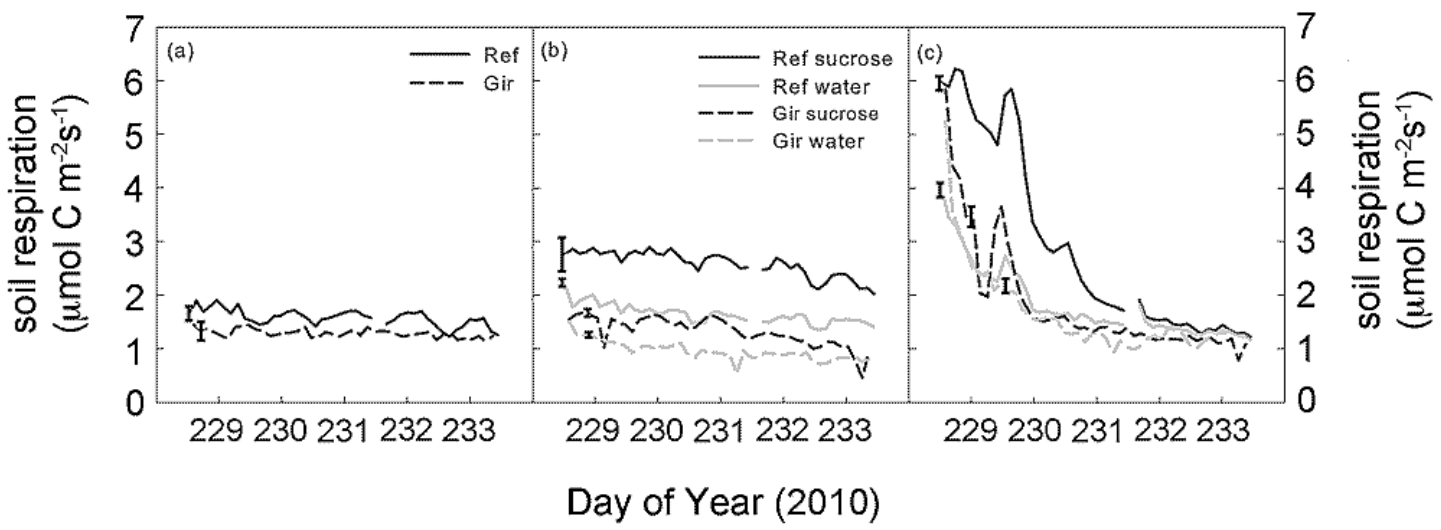

Fig. 6. Girdled-reference comparison experiment respiration response for (a) untreated chambers, (b) mineral soil surface applications, and (c) litter surface application. Error bars represent $\pm 1 \mathrm{SE}$ (within-treatment mean over all sample timepoints).

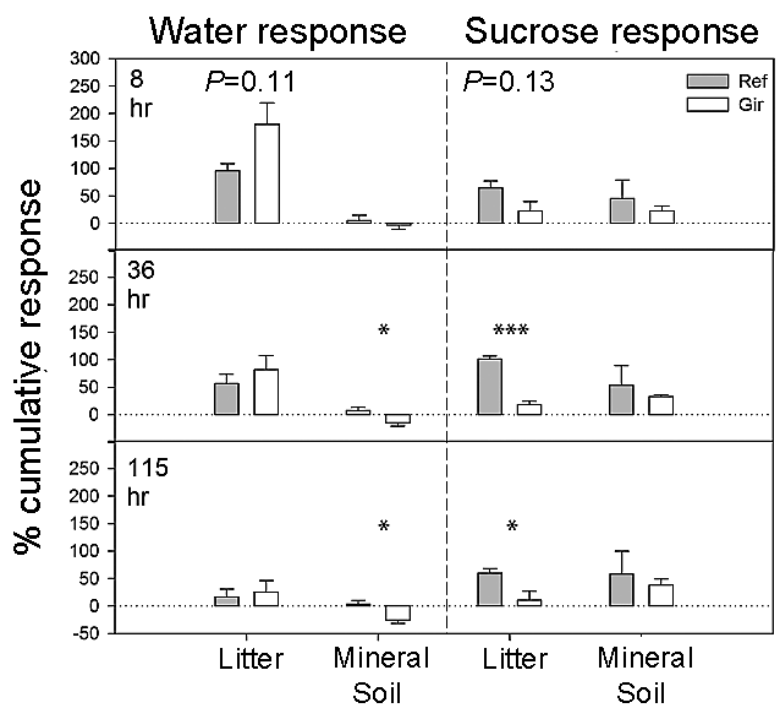

Fig. 7. Response of respiration to water and sucrose additions at the reference site (grey bars) and the girdled site (white bars). Standard error bars are shown $(n=3)$. Limitations to water and sucrose in the litter were calculated from the accumulation of respired carbon over three time periods following treatment application: from the first three measurement cycles $(8 \mathrm{~h})$, from the first $36 \mathrm{~h}$, and from the entire duration of the experiment $(115 \mathrm{~h})$, using cumulative $\mathrm{C}$ fluxes and Eq. (1). Asterisks denote significant differences between the two sites (t-test, ${ }^{*} P \leq 0.05$; ${ }^{* *} P \leq 0.01$; $\left.{ }^{* * *} P \leq 0.001\right) . P$ values are shown for tests not meeting the $\alpha$ criteria of 0.05 but were less than 0.15 .

\section{Conclusions}

In this piñon-juniper ecosystem, the response of $\mathrm{CO}_{2}$ efflux to future climate change will depend on changes in surface moisture, temperature and labile $\mathrm{C}$ availability. We propose that the Birch effect is maximized by high temperature and unlimited access to labile $\mathrm{C}$ and moisture, but that low levels of any variable would minimize the Birch effect. By girdling trees, we induced a disturbance that altered all three of these variables and found that a reduction in labile $\mathrm{C}$ limitation in the litter was the net result of these changes. Mass tree mortality events are currently affecting forests on a global scale and could increase in size and frequency with global warming (Mitton and Ferrenberg, 2012). Predicting the response of regional $\mathrm{C}$ cycling to such events requires consideration of temperature, moisture and labile $\mathrm{C}$ limitation of microbial respiration.

Acknowledgements. This research was supported by Los Alamos National Laboratory's Institute for Geophysics and Planetary Physics Minigrant Program (LA-UR \#11-10329) and by a grant from the US Department of Energy - EPSCoR to Marcy Litvak, Thom Rahn and Bob Sinsabaugh (\#DE-FG02-08ER46506). The authors would like to acknowledge the assistance of Leo Stoscheck, Daniel McInnis, and Jennifer Johnson. The authors are greatly appreciative of comments from Bob Sinsabaugh, Mike Ryan, R. Dave Evans, Jodi Johnson-Maynard, and two anonymous reviewers.

Edited by: P. Stoy

\section{References}

Birch, H. F.: The effect of soil drying on humus decomposition and nitrogen availability, Plant Soil, 10, 9-31, 1958.

Borken, W. and Matzner, E.: Reappraisal of drying and wetting effects on $\mathrm{C}$ and $\mathrm{N}$ mineralization and fluxes in soils, Glob. Change Biol., 15, 808-824, 2009.

Bosatta, E. and Ågren, G.: Soil organic matter quality interpreted thermodynamically, Soil Biol. Biochem., 31, 1889-1891, 1999.

Breshears, D. D., Cobb, N. S., Rich, P. M., Price, K. P., Allen, C. D., Balice, R. G., Romme, W. H., Kastens, J. H., Floyd, M. L., Belnap, J., Anderson, J. J., Myers, O. B., and Meyer, C. W.: Regional vegetation die-off in response to global-change-type drought, $\mathrm{P}$. Natl. Acad. Sci. USA, 102, 15144-15148, 2005.

Butnor, J., Johnsen, K., Oren, R., and Katul, G.: Reduction of forest floor respiration by fertilization on both carbon dioxide-enriched 
and reference 17-year-old loblolly pine stands, Glob. Change Biol., 9, 849-861, 2003.

Cable, J. and Huxman, T.: Precipitation pulse size effects on Sonoran Desert soil microbial crusts, Oecologia, 141, 317-324, 2004.

Carbone, M., Still, C., Ambrose, A., Dawson, T., Williams, A., and Boot, C.: Seasonal and episodic moisture controls on plant and microbial contributions to soil respiration, Oecologia, 167, 265278, 2011.

Cisneros Dozal, L., Trumbore, S., and Hanson, P.: Effect of moisture on leaf litter decomposition and its contribution to soil respiration in a temperate forest, J. Geophys. Res., 112, G01013, doi:10.1029/2006JG000197, 2007.

Conant, R., Dalla-Betta, P., Klopatek, C., and Klopatek, J.: Controls on soil respiration in semiarid soils, Soil Biol. Biochem., 36, 945-951, 2004.

Curiel Yuste, J., Baldocchi, D., Gershenson, A., Goldstein, A., Misson, L., and Wong, S.: Microbial soil respiration and its dependency on carbon inputs, soil temperature and moisture, Glob. Change Biol., 13, 2018-2035, 2007.

Davidson, E. and Janssens, I.: Temperature sensitivity of soil carbon decomposition and feedbacks to climate change, Nature, 440, 165-173, 2006.

Ekblad, A. and Nordgren, A.: Is growth of soil microorganisms in boreal forests limited by carbon or nitrogen availability?, Plant Soil, 242, 115-122, 2002.

Fierer, N. and Schimel, J.: A proposed mechanism for the pulse in carbon dioxide production commonly observed following the rapid re-wetting of a dry soil, Soil Sci. Soc. Am. J., 67, 798-805, 2003.

Gallo, M., Porras-Alfaro, A., Odenbach, K., and Sinsabaugh, R. L.: Photoacceleration of plant litter decomposition in an arid environment, Soil Biol. Biochem., 41, 1433-1441, 2009.

Greenwood, D.: The effect of oxygen concentration on the decomposition of organic materials in soils, Plant Soil, 14, 360-376, 1961.

Griffin, J. M., Turner, M. G., and Simard, M.: Nitrogen cycling following mountain pine beetle disturbance in lodgepole pine forests of Greater Yellowstone, Forest Ecol. Manag., 261, 10771089, 2011.

Huxman, T., Snyder, K., Tissue, D., Leffler, A., Ogle, K., Pockman, W., Sandquist, D., Potts, D., and Schwinning, S.: Precipitation pulses and carbon fluxes in semiarid and arid ecosystems, Oecologia, 141, 254-268, 2004.

Jenerette, G. D., Scott, R. L., and Huxman, T. E.: Whole ecosystem metabolic pulses following precipitation events, Funct. Ecol., 22, 924-930, 2008.

Kelliher, F., Ross, D., Law, B., Baldocchi, D., and Rodda, N.: Limitations to carbon mineralization in litter and mineral soil of young and old ponderosa pine forests, Forest Ecol. Manag., 191, 201-213, 2004.

Kim, D.-G., Vargas, R., Bond-Lamberty, B., and Turetsky, M. R.: Effects of soil rewetting and thawing on soil gas fluxes: a review of current literature and suggestions for future research, Biogeosciences, 9, 2459-2483, doi:10.5194/bg-9-2459-2012, 2012.

Lloyd, J. and Taylor, J.: On the temperature dependence of soil respiration, Funct. Ecol., 8, 315-323, 1994.

McCalley, C. K. and Sparks, J. P.: Abiotic gas formation drives nitrogen loss from a desert ecosystem, Science, 326, 837-840, 2009.
Mitton, J. B. and Ferrenberg, S. M.: Mountain pine beetle develops an unprecedented summer generation in response to climate warming, Am. Nat., 179, E163-E171, 2012.

Morehouse, K., Johns, T., Kaye, J., and Kaye, M.: Carbon and nitrogen cycling immediately following bark beetle outbreaks in southwestern ponderosa pine forests, Forest Ecol. Manag., 255, 2698-2708, 2008.

Nottingham, A. T., Turner, B. L., Chamberlain, P. M., Stott, A. W., and Tanner, E. V. J.: Priming and microbial nutrient limitation in lowland tropical forest soils of contrasting fertility, Biogeochemistry, 111, 219-237, 2009.

Oren, A. and Steinberger, Y.: Coping with artifacts induced by $\mathrm{CaCO}_{3}-\mathrm{CO}_{2}-\mathrm{H}_{2} \mathrm{O}$ equilibria in substrate utilization profiling of calcareous soils, Soil Biol. Biochem., 40, 2569-2577, 2008.

Parton, W. J., Ojima, D., Cole, C., and Schimel, D.: Quantitative Modeling of Soil Forming Processes, chap. A general model for soil organic matter dynamics: sensitivity to litter chemistry, texture and management, Soil Sci. Soc. Am., Madison, WI, 147167, 1994.

Plummer, L. and Busenberg, E.: The solubilities of calcite, aragonite and vaterite in $\mathrm{CO}_{2}-\mathrm{H}_{2} \mathrm{O}$ solutions between 0 and $90^{\circ} \mathrm{C}$, and an evaluation of the aqueous model for the system $\mathrm{CaCO}_{3}-\mathrm{CO}_{2}-$ $\mathrm{H}_{2} \mathrm{O}$, Geochim. Cosmochim. Ac., 46, 1011-1040, 1982.

Potts, D. L., Huxman, T. E., Cable, J. M., English, N. B., Ignace, D. D., Eilts, J. A., Mason, M. J., Weltzin, J. F., and Williams, D. G.: Antecedent moisture and seasonal precipitation influence the response of canopy-scale carbon and water exchange to rainfall pulses in a semi-arid grassland, New Phytol., 170, 849-860, 2006.

Reynolds, J., Kemp, P., Ogle, K., and Fernández, R.: Modifying the "pulse-reserve" paradigm for deserts of North America: precipitation pulses, soil water, and plant responses, Oecologia, 141, 194-210, 2004.

Saetre, P. and Stark, J.: Microbial dynamics and carbon and nitrogen cycling following re-wetting of soil beneath two semi-arid plant species, Oecologia, 142, 247-260, 2005.

Sala, O. E. and Lauenroth, W. K.: Small rainfall events: an ecological role in semiarid regions, Oecologia, 53, 301-304, 1982.

Schaeffer, S., Billings, S., and Evans, R.: Responses of soil nitrogen dynamics in a Mojave Desert ecosystem to manipulations in soil carbon and nitrogen availability, Oecologia, 134, 547-553, 2003.

Schimel, J. and Weintraub, M.: The implications of exoenzyme activity on microbial carbon and nitrogen limitation in soil: a theoretical model, Soil Biol. Biochem., 35, 549-563, 2003.

Schwinning, S. and Sala, O.: Hierarchy of responses to resource pulses in arid and semi-arid ecosystems, Oecologia, 141, 211220, 2004.

Serrano-Ortiz, P., Roland, M., Sanchez-Moral, S., Janssens, I., Domingo, F., Goddéris, Y., and Kowalski, A.: Hidden, abiotic $\mathrm{CO}_{2}$ flows and gaseous reservoirs in the terrestrial carbon cycle: Review and perspectives, Agr. Forest Meteorol., 150, 321-329, 2010.

Sherrod, L., Dunn, G., Perterson, G., and Kolberg, R.: Inorganic carbon analysis by modified pressure-calcimeter method, Soil Sci. Soc. Am. J., 66, 299-305, 2002.

Sponseller, R.: Precipitation pulses and soil $\mathrm{CO}_{2}$ flux in a Sonoran Desert ecosystem, Glob. Change Biol., 13, 426-436, 2007.

Suseela, V., Conant, R., Wallenstein, M., and Dukes, J.: Effects of soil moisture on the temperature sensitivity of heterotrophic 
respiration vary seasonally in an old-field climate change experiment, Glob. Change Biol., 18, 336-348, 2011.

Witkamp, M.: Decomposition of leaf litter in relation to environment, microflora, and microbial respiration, Ecology, 47, 194201, 1966.
Ziegler, S. E. and Billings, S. A.: Soil nitrogen status as a regulator of carbon substrate flows through microbial communities with elevated $\mathrm{CO}_{2}$, J. Geophys. Res., 116, G01011, doi:10.1029/2010JG001434, 2011. 